\title{
Hoy Garantías Ecológicas, ayer Garantías Sociales
}

\author{
Gabriel Quesada ${ }^{1}$
}

Costa Rica es un país de gran riqueza ecológica y humana por su localización y características físicas al ubicarse entre dos masas continentales, América del Norte y América del Sur, el país posee una rica biodiversidad de especies continentales migratorias y endémicas. A nivel humano, la situación no es diferente. Costa Rica ha sido la frontera Sur de Mesoamérica, como la frontera norte de Sudamérica. Diferentes grupos aborígenes habitaron nuestras tierras, enriqueciendo su diversidad cultural y étnica.

Científicamente se ha demostrado que el país cuenta con el $5 \%$ de las especies del planeta, en un territorio de 51.100 kilómetros cuadrados, el 0,04\% de la superficie de la tierra. Un área tan pequeña aproximadamente 12.000 especies de plantas que se dividen en 10.000 especies de plantas vasculares y una 2.000 especies de plantas no

1. Biólogo costarricense. Especialista en ecología aplicada. 
vasculares. La diversidad y el número de animales no dejan de ser importantes: existen unas 300.000 especies de insectos, 848 especies de aves, 237 especies de mamíferos, 218 especies de reptiles, 143 especies de anfibios, 15.000 especies de peces continentales y unas 800 especies de peces marinos.

Esta riqueza ecológica y cultural ha sido base del desarrollo político, económico y social de los grupos aborígenes. Su filosofía y visión del cosmos y del mundo estaban sustentadas en los fenómenos naturales.

Con la conquista española se inicia una transformación cualitativa y cuantitativa de los patrones culturales y ecológicos del país. Primero por el interés de esa monarquía en consolidar su poder económico y político a nivel internacional y segundo, en explotar los recursos naturales y humanos que le permitieran consolidar su imperio.

La colonia mantuvo los patrones de administración y explotación de recursos similares a los de la conquista.

Es con la introducción del café en la economía que el país se consolida como república y se inicia una nueva etapa en la historia nacional. El ecosistema natural se transforma en un agroecosistema, donde se combinan especies de árboles de la flora costarricense con las plantas del café. El bosque artificial estaba compuesto principalmente por leguminosas que no solo daban sombra al cafeto, sino que aportaban nitrato al suelo, también era parte importante en la formación de nutrientes en los antiguos cafetales. Sin embargo, a partir de la década del 50 , los agroecosistemas tradicionales del café se cambiaron por plantaciones con poca cubierta vegetal o por plantaciones expuestas al sol. Este cambio, trajo como consecuencia la introducción de agroquímicos, como fertilizantes y pesticidas que provocaron un impacto negativo en el ambiente por su uso indiscriminado. Otro serio contaminante ha sido el lanzamiento de 
broza y mieles a ríos y riachuelos del Valle Central, producto del procesamiento industrial del café.

$\mathrm{La}$ actividad bananera fue otro factor que transformó el ecosistema costarricense. La construcción del ferrocarril en la zona caribeña favoreció a las compañías extrajeras con la concesión de miles de hectáreas para la explotación del banano. Años más tarde la expansión se trasladó a la zona del Pacífico Central y Sur y más recientemente a la región Huetar Norte. En la actualidad muchas de las viejas zonas. bananeras han sido abandonadas por agotamiento y acumulación de cobre en los suelos. El uso de agroquímicos sin el control y regulaciones adecuadas, produjo la esterilización masiva de seis mil trabajadores bananeros en la zona de Río Frío, provincia de Heredia. Los trabajadores y sus abogados cobran sumas cuantiosas a las compañías bananeras, como indemnización por los daños producidos en su sistema reproductivo.

Como consecuencia un grupo de costarricenses presentó un juicio sin precedentes ante el Tribunal Internacional del Agua en el año de 1992. Dicho Tribunal fue auspiciado por el Gobierno de Holanda, con el respaldo de la Unión Europea y la comunidad científica internacional. Los resultados del juicio fueron de gran trascendencia para Costa Rica, toda vez que se establece la primera jurisprudencia ecológica frente a una empresa bananera transnacional.

Durante la década de los años 50 se introdujo otra actividad no menos perjudicial que el banano, la ganadería extensiva. Ésta ha sido la responsable de la destrucción de casi el $50 \%$ de bosque primario y secundario a nivel nacional y elevó la tasa de deforestación a 60.000 hectáreas por año. Esta actividad ha sido también responsable de la erosión de millones de toneladas de suelo productivo y de la desaparición del hábitat de gran cantidad de especies de 
aves, insectos y mamíferos y también contribuyó a que muchos campesinos migraran del campo a la ciudad en busca de fuentes de trabajo. La proliferación de ciudades satélites alrededor del área metropolitana es creciente y muchas familias viven en la pobreza extrema, con serios problemas de delincuencia y de salud.

Otro problema serio es la contaminación de las aguas en las principales cuencas hidrográficas del Valle Central. Miles de toneladas métricas de materia fecạl, además de los residuos del café, son depositadas sin tratamiento alguno a estos ríos. Recientemente han proliferado enfermedades infecto-contagiosas, como el dengue, la malaria, el sarampión y el cólera que podrían estar relacionadas con la contaminación de las aguas. Tampoco existe control sobre los compuestos químicos como metales pesados, detergentes, agroquímicos y otros altamente tóxicos, que también van a dar a las redes hidrográficas. Se ha determinado que los desechos fecales y químicos que son transportados por la red hídrica del Grande de Tárcoles, son depositados por corrientes marinas en el Golfo de Nicoya, situación que ha provocado una disminución en la pesca y un conflicto económico serio para la mayor parte de los pescadores de la zona de Puntarenas.

Diariamente se producen miles de toneladas métricas de basura en el Valle Central. Ante este problema tan serio los representantes del Poder Ejecutivo y las Municipalidades no han dado una respuesta científico-técnica a la administración y manejo de los desechos sólidos. Existe hoy un rechazo por parte de las municipalidades a aceptar los rellenos sanitarios en sus comunidades debido a los malos procedimientos empleados por las autoridades y los intereses particulares que se manejan de esta situación.

En muchos casos, los desechos sólidos se lanzan a ríos, lotes y vías de comunicación, produciendo un serio impacto estético y paisajístico. 
El uso sin control de agroquímicos contribuye a la contaminación de otras zonas de pesca en el país. Es así como una gran cantidad de arrecifes de coral en la costa Caribe ha desaparecido por contaminación de plaguicidas y pesticidas utilizados en las plantaciones bananeras, acabando con el $75 \%$ de los arrecifes coralinos localizados al Sur del río la Estrella. Al eliminarse el arrecife, la ictiofauna ha disminuido considerablemente y muchos pescadores de Cahuita, Puerto Viejo y Manzanillo se han perjudicado por la destrucción de estos ecosistemas marinos. Además, la construcción del muelle de Limón alteró el régimen de corrientes marinas, provocando la erosión del litoral y la sedimentación de partículas en las colinas coralinas. Otro factor que ha alterado la zona del Caribe, es el crecimiento y construcción desordenado de hoteles y vivienda desde Puerto Viejo hasta Manzanillo. Se han violado leyes que regulan la contaminación en refugios de vida silvestre, reservas indígenas y la zona marítima terrestre, todo por falta de ética administrativa y controles ambientales a quienes la ley obliga.

En la costa Pacífica la situación no deja de ser menos grave. Se construyen hoteles en todo el litoral sin la adecuada protección del litoral, los concesionarios adeudan millones de colones al estado por derechos de ocupación. Tampoco se exigen una evaluación de impacto ambiental antes de otorgar los permisos de construcción. Las playas nacionales se convirtieron en lugares de difícil acceso para los costarricenses. El Río Tempisque, principal fuente de agua en la provincia de Guanacaste, sufre también el impacto de la contaminación producida por plaguicidas provenientes de zonas algodoneras, arroceras y ganaderas.

En los últimos veintiocho años se han gestado grandes cambios en el sistema jurídico, administrativo y social para proteger el ambiente. Nacen los primero grupos 
ecologistas y se crean las áreas protegidas en todo el territorio nacional. Se establecen instituciones públicas para administrar las áreas protegidas y se crean fondos privados para financiar proyectos ambientales.

Sin embargo, es a raíz de la discusión del proyecto geotérmico de Miravalles, propuesto por el Comité de Defensa del Patrimonio Nacional en la Asamblea Legislativa que se plantea la urgente necesidad de introducir en la Constitución Política un título único de Garantías Ecológicas, la creación de un Código del Ambiente, el establecimiento de una Comisión de Ambiente en el primer poder de la República, así como un Ministerio del Ambiente, organismo administrativo capaz de fijar políticas ecológicas en el ámbito nacional. En años posteriores, se propuso en la Asamblea Legislativa crear una ley para proteger y establecer reglas del juego que aseguren el uso adecuado de nuestra diversidad biológica. La ley de biodiversidad, aprobada en años anteriores, forma parte de la resolución ecológicojurídico que ha experimentado el país a partir de la necesidad de proteger los ecosistemas, la riqueza biológica (bioquímica y genética) y no repetir los errores que se cometieron en el pasado. La ley reafirma la soberanía del estado costarricense sobre la biodiversidad y sus elementos, sin embargo, diferentes organizaciones que participaron en la redacción de la ley se opusieron a incluir como parte del dominio público la flora costarricense. Todavía prevalecen los intereses individuales a los intereses colectivos, incluso en organizaciones que se declaran defensoras del ambiente. Lo que sí es un hecho claro y cierto, es que los bosques naturales han prácticamente desaparecido y todavía continúa explotando el bosque con las viejas prácticas depredadoras del pasado. El estado tiene el deber de proteger los últimos reductos de biomasa vegetal que se encuentran en el país. Las áreas protegidas (parques nacionales, refugios 
de vida silvestre, reservas biológicas, etc.) no deben bajo ninguna circunstancia privatizarse o ceder su administración a entes privados. Deben corregirse las definiciones existentes, pero no acabar con un sistema que ha costado muchos años de lucha y sacrificio.

Es deber de todos los costarricenses proteger nuestros recursos naturales, ya que en una democracia participativa, todos somos parte del estado. En nuestras manos está ejercer ese derecho y contribuir efectivamente a la protección y uso racional de la gran diversidad biológica que hemos heredado. En la actualidad muchos de estos proyectos ya son leyes de la República, gracias a la lucha que distinguidos costarricenses realizaron en pro del ambiente.

Además, se incorporó en la Constitución Política (art 50), un primer párrafo sobre el derecho a un ambiente sano y la responsabilidad del estado a garantizar, defender y preservar ese derecho.

La enmienda al artículo 50 de la Constitución, el establecimiento de la Ley Orgánica del Ambiente, la Ley sobre Biodiversidad, la creación del Ministerio del Ambiente, entre otras, son parte de la gran transformación jurídico-administrativo que experimenta el país en este milenio. Sin embargo, estos derechos, deberes y obligaciones que tiene el estado y la sociedad cambian muy lentamente y los problemas ambientales (agua, aire, energía, vida silvestre (marina y terrestre), minas y crecimiento urbano aumenta en muchos casos exponencialmente. Ni el gobierno, ni la empresa privada, ni la sociedad han dado respuestas y soluciones contundentes a tan grave situación.

Por lo tanto, es fundamental incluir en la Constitución Política un título de Garantías Ecológicas que responda al interés público ambiental, para que los derechos ecológicos sean debidamente tutelados por el Recurso de Amparo y la Acción de Inconstitucionalidad, como derechos 
fundamentales. Por otra parte, es importante tipificar el delito ecológico a través de una ley penal del ambiente, para que el ciudadano y el pueblo costarricense cuenten con un instrumento ágil y eficiente y pueda exigir una verdadera protección de los ecosistemas, ergo su vida y existencia en el planeta tierra. 